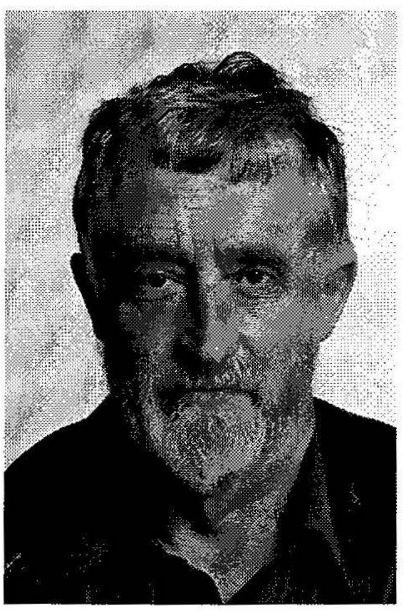

\title{
INFORMATION TECHNOLOGY USE AND EMPLOYMENT CHANGE IN NEW ZEALAND INDUSTRIES
}

\author{
Chris Hector ${ }^{1}$ \\ University of Waikato
}

\begin{abstract}
The last quarter of the $20^{\text {th }}$ century was marked by rapid uptake of new information and communication technologies (ICT) with far-reaching effects in workplace organization. These changes have consequent effects on demand patterns in the labour market, with less educated workers facing declining opportunities. In this paper Census of Population data from 1991, 1996 and 2001 are used to investigate changes in employment demand by education level for full-time workers in 58 industries covering the entire New Zealand economy. To explore the role of technical change, data on industry use of computers from the 1996 Input-Output tables are related to the changes in employment levels for workers at different levels of education. The findings suggest that declining employment opportunities for workers who only have school level qualifications or less are strongly concentrated amongst the industries with higher ICT uptake.
\end{abstract}

\section{Introduction}

In the middle years of the $20^{\text {th }}$ century there was little unemployment in the OECD countries, but unemployment has risen significantly in New Zealand and in other developed countries in recent years (Martin, 1994; Nickell and Bell, 1995), and particularly afflicts workers at the lower end of the skills range. This decline in employment opportunities is coincident with the rapid diffusion of computers and other information technologies, so skill-biased technical change is one of the leading explanations for the changing pattern of employment opportunities (Goldin and Katz, 1998). The possible link between information and communication technologies (or ICTs) and changing labour market demand poses a potential problem for public policies that aim to expand the use of ICT in the economy. For example, in New Zealand the ICT sector has recently been recognised by the government as one of three priority sectors, due to its potential to improve productivity across the economy. ${ }^{1}$ At the same time, however, the government recognises that: "in an information society, there is the potential for an inequitable distribution of ICT which exacerbates existing social and economic disparities."

Given this potential tradeoff between greater productivity and wider inequality, it is important to identify the effect of ICTs on the distribution of employment opportunities for the NZ population, and this paper reports on preliminary attempts to examine the link between computer use and employment change across different industries. Specifically, Census of Population data from 1991, 1996 and 2001 are used to estimate trends in employment change by educational level for full-time workers in 58 industries covering the entire New Zealand economy. To explore the role of technical change, data on industry use of computers from the 1996 Input-Output tables are related to the changes in employment levels for workers at different levels of education.

The next section of the paper reviews the literature on the labour market effects of technological change. In Section III the data and methods of analysis are discussed, while Section IV contains the results of econometric investigations into the link between industry computer use and labour demand.

\footnotetext{
${ }^{1}$ Department of Economics, University of Waikato, Private Bag 3105, Hamilton. Phone: (7) 856-2889. E-mail: chector@waikato.ac.nz. The financial support of grant UOWX0016 from the Foundation for Research, Science and Technology is gratefully acknowledged.
} 


\section{Review of the Literature}

In the more developed economies the mid twentieth century was a period of full employment and relatively narrow margins for skill, but this pattern began to change quite suddenly in the 1970 s. The last twenty five years have seen significant unemployment, especially though not exclusively among the less educated. Coinciding with this there has been a steady rise in the returns to education. This pattern is widespread among OECD members (Nickell and Bell, 1995) but particularly pronounced in the English speaking countries. The United Kingdom and the United States are the most extreme cases (Atkinson, 2001; Martin, 1994), with a similar pattern evident in New Zealand (Borland, 2000; Dixon, 1998).

Since the end of World War II the numbers of school leavers continuing to tertiary education has been increasing steadily in OECD countries, but during the 1960 s and early 1970 s this trend was accompanied by a decline in the returns to education as the supply of more qualified workers outstripped demand (Juhn, 1999). The recent pattern of declining employment opportunities for the less skilled coupled to an increasing skills premium, at a time when the supply of skilled workers has been increasing, indicates that the demand for skills has been growing even faster than supply (Juhn, Murphy and Pierce, 1993; Pryor and Schaffer, 1999), and since 1980 the demand for the less skilled has plummeted (Berman, Bound and Machin, 1998).

The period when the advantage enjoyed by skilled with respect to less skilled workers began to widen was also a period of rapidly changing technology in the workplace. This could be coincidence, and a number of other reasons such as declining union power and changing industrial structures in the face of globalization have been advanced (Levy and Murnane, 1992; Wood, 1995). However none of the alternatives suggested seem likely to have caused the observed outcomes (Lawrence, 1995; Murphy and Welch, 1993), and skill biased technological change, while not the proven cause, is currently the prime candidate (Bound and Johnson, 1995; Goldin and Katz, 1998).

The widespread belief that technological change is the primary source of economic growth (Landau, Taylor and Wright, 1996) has given rise to extensive research into different kinds of technology and the nature of technological change. Some technologies, especially those relating to specific industries, evolve progressively and display steady incremental improvements rather than more radical innovations (Freeman, 1992: 77). In contrast, "General Purpose Technologies" or GPTs (Bresnahan and Trajtenberg, 1995; David, 2000) spark a revolutionary change in modes of production, affecting countless industries. Examples of GPTs include steam power in the nineteenth century and electrification at the turn of the century (Helpman, 1998). Many authors have suggested that information and communication technologies (hereafter ICT) represent the latest of these General Purpose Technologies (Brynjolfsson and Hitt, 2000). For example, the general purpose nature of cheaper and better ICT permits co-invention of more and more complex uses (Bresnahan, 1999: F402).

Whether a new general purpose technology, such as ICT, raises or lowers the demand for skills can only be determined empirically. Either outcome is possible depending on which segment of the labour market is most affected and the nature of the impact. For example, several studies have suggested that nineteenth century technological advances were generally unskill-biased, but that this pattern has been reversed in the twentieth century (Acemoglu, 2002), with labour demand moving in favour of the more skilled:

"The observed evolution of relative wages, employment, and wage bill shares by education and occupation throughout the twentieth century would appear to require a rapid and persistent secular growth in the relative demand for more educated workers" (Goldin and Katz, 1998: 704).

A causal link between increasing use of technology and the decline in demand for less skilled workers is widely accepted as very plausible, since returns to schooling have been found to be higher in industries making greater use of advanced technology (Allen, 1996). Moreover, the rate of skill upgrading has tended to be greatest in industries with greater computer investment (Autor, Katz and Krueger, 1998; Johnson, 1997). However, it may be that rather than a simple complementarity between computer use and individual workers' skills, there is a complementarity between skilled workers and an automated workplace (DiNardo and Pischke, 1997).

Computerization appears to be strongly associated with occupational restructuring (Brynjolfsson and Hitt, 2000; Wolff 2002), with better educated workers enjoying a comparative advantage in implementing new technology (Bartel and Lichtenberg, 1987).

Since the pioneering work of Richard Nelson and Edmund Phelps in the $1960 \mathrm{~s}$, it has been appreciated that better educated workers are better equipped for decision making in all areas, and not merely their own field of specialization (Nelson and Phelps, 1966; Huffman, 1974). There is significant evidence to suggest that the workplace reorganisation facilitated by ICT has boosted demand, not so much for ICT specialists, as for the generally well educated workers who are best able to adapt to and operate in a rapidly changing environment (Howell and Wolff, 1992; Schultz, 1993).

\section{Data and Methods}

Census of Population data were obtained for 1991, 1996 and 2001 on the numbers of workers in each industry and their highest qualification gained. The sample was restricted to full-time workers, in part because a related set of analyses 
looked at changes in annual earnings, which are easiest to identify with changes in the distribution of wages for full-time workers. Thus, while the following results do not cover the full population they do relate to the largest group in the New Zealand workforce. According to the Census, there were 891,210 full-time employees in $1991 \quad(535,539$ male and 355,674 female), rising to 939,162 full-time employees in 1996 and 997,332 in $2001(572,244$ male and 425,088 female). Hence female workers increased their share of the full-time workforce from $39.9 \%$ to $42.6 \%$.

Some basic characteristics of the data from the Census are shown in Table 1. The figures show a broad trend toward more workers with university degrees, both at the bachelor's and at the post-graduate levels. Workers holding degrees rose from 9.8 percent of the full-time workforce in 1991 to 12.9 percent in 1996 and $16.1 \%$ in 2001, however this rise was entirely achieved at the expense of other post-secondary qualifications, and the proportion of workers with no qualification beyond the University Entrance $/ 6^{\text {th }}$ form level increased from $48.9 \%$ in 1991 to $54.7 \%$ in 2001 . By 2001 the proportion of female workers who were university graduates had overtaken that of male workers, and at the lower end of the qualification scale female workers also displayed significantly higher completion rates than males, with only $24.3 \%$ of female workers lacking even School Certificate compared to $31.7 \%$ of male workers.

One problem affecting the estimation of a skills demand function from self-reported qualifications lies in the changing use of terminology and the expansion of degree-granting polytechnic courses. Many qualifications, such as accountancy and primary school teaching, are today recognized with university degrees though in earlier years qualifications were granted by professional bodies or non-degree granting institutions.

Of the 62 industries that the working population was categorised into, three were excluded from the analysis because their very small numbers of workers caused a large number of empty cells: Industries 5 (hunting and trapping), 53 (owner-occupied housing) and 61 (domestic service). ${ }^{3}$ Furthermore, industry 22 (oil refining) was also excluded as there is only one firm in the industry in New Zealand, and the information is therefore both firm-specific and industry-specific. Of the 58 remaining industries, the largest was wholesale and retail trade, with 128,004 fulltime workers in 1991, rising to 162,477 in 2001. In 1991 this was followed by public administration and defence $(76,896)$, education $(65,238)$ and business services $(56,223)$. By 2001 this order had changed somewhat with education $(83,115)$ and business services $(85,110)$ rising while public administration and defence dropped $(64,899)$. The smallest industries in each year were coal mining, oil and gas extraction and petrol and coal products, with fewer than 1000 full-time workers each in 1991 and all continuing to decline over the next decade. The estimation methods used take account of these large differences in the size of each industry.

Prior to 1997 Statistics New Zealand used the New Zealand Standard Industrial Classification (NZSIC) to differentiate industries, but since then they have adopted the Australian and New Zealand Standard Industrial Classification (ANZSIC). The Census data from 1991 and 1996 are therefore directly comparable, but the design of the ANZSIC classification results in a number of regroupings which complicate some industry comparisons between 1996 and 2001. Translation between the classifications is relatively straightforward for 54 of the 58 industries, covering some $94 \%$ of the full-time workforce. Of the remaining four industries, two (manufacture of professional equipment and sanitary and cleaning services) have been regrouped in such a fundamentally different manner as to make comparison invalid, but together they only account for 28,122 workers in 2001 , or $2.8 \%$ of the full-time workforce. Two further industries (banking and other financial services) have been redefined in such a way that some 5000 workers classified as banking under NZSIC are now included in other financial services. For the purpose of comparison between 1996 and 2001 these two industries have therefore been combined into a single financial services industry of 32,073 full-time workers.

Table 1. N.Z. Census data for full-time employees by gender and highest qualification

\begin{tabular}{|c|c|c|c|c|c|c|c|c|c|}
\hline \multirow{2}{*}{$\begin{array}{l}\text { Highest } \\
\text { Qualificaton }\end{array}$} & \multicolumn{3}{|c|}{1991} & \multicolumn{3}{|c|}{1996} & \multicolumn{3}{|c|}{2001} \\
\hline & Males & Females & Total & Males & Females & Total & Males & Females & Total \\
\hline No qualification & $29.5 \%$ & $28.2 \%$ & $29.0 \%$ & $30.3 \%$ & $26.1 \%$ & $28.6 \%$ & $31.7 \%$ & $24.3 \%$ & $28.5 \%$ \\
\hline School Cert & $10.2 \%$ & $14.1 \%$ & $11.7 \%$ & $11.0 \%$ & $14.3 \%$ & $12.4 \%$ & $13.8 \%$ & $15.6 \%$ & $14.6 \%$ \\
\hline UE/6th Form & $7.3 \%$ & $9.5 \%$ & $8.2 \%$ & $9.5 \%$ & $12.0 \%$ & $10.6 \%$ & $10.7 \%$ & $12.8 \%$ & $11.6 \%$ \\
\hline Bursary & $3.1 \%$ & $2.7 \%$ & $3.0 \%$ & $4.7 \%$ & $4.6 \%$ & $4.7 \%$ & $5.5 \%$ & $5.3 \%$ & $5.4 \%$ \\
\hline Diploma & $39.6 \%$ & $36.4 \%$ & $38.3 \%$ & $31.6 \%$ & $30.0 \%$ & $30.9 \%$ & $23.7 \%$ & $23.9 \%$ & $23.8 \%$ \\
\hline Bachelor & $6.3 \%$ & $6.0 \%$ & $6.2 \%$ & $8.2 \%$ & $8.9 \%$ & $8.5 \%$ & $9.4 \%$ & $12.6 \%$ & $10.8 \%$ \\
\hline Postgraduate & $3.9 \%$ & $3.1 \%$ & $3.6 \%$ & $4.7 \%$ & $4.1 \%$ & $4.4 \%$ & $5.2 \%$ & $5.4 \%$ & $5.3 \%$ \\
\hline $\begin{array}{l}\text { Number of } \\
\text { Worker }\end{array}$ & 535,539 & 355,674 & 891,210 & 551,718 & 387,447 & 939,162 & 572,244 & 425,088 & 997,332 \\
\hline
\end{tabular}

The Census data were used to estimate a labour-skills demand function for full time workers of each qualification level, in each industry and each census year, where the dependent variable is the proportional change in numbers employed $(E)$ in each industry (i) and year ( $t$ ), which is regressed on computer use and other industry variables: 
(1) $\frac{\left(\mathrm{E}_{\mathrm{i}(\mathrm{t}+5)}-\mathrm{E}_{\mathrm{it}}\right)}{\left(\mathrm{E}_{\mathrm{it}}\right)}=f($ computer use, other industry controls).

Although equation (1) posits a causal relationship, with changing employment patterns modelled as dependant on computer use, it is not intended to rule out the possibility of the reverse relationship. A greater proportion of high-skill workers could theoretically be the exogenous variable, with the changed workforce then needing to be equipped with computers.

\section{Measures of Industry Use of Information and Communications Technologies (ICT)}

There is no generally accepted best proxy for the uptake of new technologies. Some proxies that have been used include R \& D expenditure, age of capital, use of patents, and expenditure on ICT equipment and services (Bartel and Sicherman, 1999). The present study uses industry expenditure on computers and computer services drawn from the 1996 inter-industry tables compiled by Statistics New Zealand. These are published at two levels of detail, neither of which exactly matches the 62 industry division used for the Census data, so the more detailed 126 industry by 210 product version was chosen and a concordance was created to regroup this industry specification to match the Census. (Concordance available on request).

In the inter-industry tables values less than one million dollars are suppressed. Of the 58 industries, there were 11 with software and computer services expenditure and 25 with hardware purchases below this threshold in 1996. One option is to set these missing values to zero, though the other extreme would be to set them to $\$ 0.5 \mathrm{M}$ (on the assumption that any higher amount would have been rounded to $\$ 1 \mathrm{M}$ and reported). Alternatively, rather than making adjustments which operate only on the numerator of the ratio between computer spending and total industry outlay, it is possible to adjust the ratio itself, replacing missing values with either the lowest non-missing ratio or the mean of the non-missing ratios. In the analysis which follows all these alternative approaches to handling missing variables were tested, and the findings appear to be robust to any of these assumptions. The reported results are those with missing values set to zero ${ }^{4}$.

In contrast to the industries making very little use of computing, there were five industries that had total computer and computer services purchases in excess of $\$ 100 \mathrm{~m}$ in 1996 . Wholesale and retail trade is the biggest with a total of approximately $\$ 370 \mathrm{~m}$, followed by banking, other financial services and business services, each at over $\$ 250 \mathrm{~m}$ and government administration at $\$ 180 \mathrm{~m}$. When purchases of computers and computer services are expressed relative to the size of the industry (in terms of total outlays), the sectors with the most intensive use of computers are banking, finance, insurance, business services and public administration."

\section{Computer Use and Changes in Employment Between Skill Groups}

Table 2 shows the proportional change in numbers of workers at each skill level over each of the intercensal periods. There are overall trends in total employment, which grew $5.4 \%$ from 1991 to 1996 and $6.2 \%$ from 1996 to 2001 (as well as being higher for female workers than male), so to focus on the changing employment demand by skill level the employment changes in table 2 have been calculated relative to the change in total employment, using equation (2):

$$
\left\{\frac{\left(E_{i(t+5)}-E_{i t}\right)}{\left(E_{i t}\right)}\right\} /\left\{\frac{\left(E_{(t+5)}-E_{t}\right)}{\left(E_{t}\right)}\right\}
$$

In table 2 ratios greater than 1 indicate categories of worker with numbers rising faster than the overall trend, those with ratios which are positive but less than 1 are growing more slowly than the overall trend, and those which are negative are categories in absolute decline.

These figures highlight the rapid increase in the proportions of the workforce with university degrees, and the steadily declining proportions of workers, both male and female, whose highest qualification is a vocational training diploma.

Table 2. Employment change by educational level as a proportion of overall change

\begin{tabular}{|c|c|c|c|c|c|c|}
\hline \multirow[t]{2}{*}{$\begin{array}{c}\text { Highest } \\
\text { Qualification }\end{array}$} & \multicolumn{3}{|c|}{$\begin{array}{c}\text { Proportional change } \\
1991-1996 \\
\end{array}$} & \multicolumn{3}{|c|}{$\begin{array}{c}\text { Proportional change } \\
1996-2001 \\
\end{array}$} \\
\hline & Males & Females & Total & Males & Females & Total \\
\hline No qualification & 1.88 & 0.11 & 0.72 & 2.28 & 0.21 & 0.98 \\
\hline School Cert & 3.72 & 1.23 & 2.06 & 8.01 & 2.04 & 4.04 \\
\hline UE/6th Form & 11.59 & 4.22 & 6.74 & 4.44 & 1.71 & 2.68 \\
\hline Bursary & 18.41 & 9.17 & 12.12 & 5.46 & 2.79 & 3.72 \\
\hline Diploma & -5.87 & -1.16 & -2.78 & -5.96 & -1.28 & -2.95 \\
\hline Bachelor & 10.78 & 6.98 & 8.18 & 5.29 & 5.72 & 5.69 \\
\hline Postgraduate & 7.18 & 4.97 & 5.47 & 4.24 & 4.78 & 4.44 \\
\hline Total & 1.00 & 1.00 & 1.00 & 1.00 & 1.00 & 1.00 \\
\hline
\end{tabular}


A variety of regressions were estimated to see whether the changing proportions of workers at each educational level were related in any way to the importance of computers in each of the various industries. The initial estimates used a bivariate version of equation (1), with industry computer use measured as the ratio of all computer expenditure (including hardware, software and computer services) to total industry outlay. The regressions were estimated for all workers together, and also for male and female workers separately, and the coefficients are reported in table 3 .

The proportion of industry expenditure devoted to computing appears to be significantly related to the changes in the demand for skills. There is a strong and statistically significant correlation between industry computer expenditure and the proportionate change in the number of workers with no qualification beyond school level. This is particularly true for workers with no qualifications beyond $6^{\text {th }}$ form or bursary, for whom the coefficients are between minus 15 and minus 18 over the 1991-1996 period. The implication of these findings is that for workers with no qualifications beyond upper secondary school level, between 1991 and 1996 there would have been a $15 \%$ to $18 \%$ decline in employment for every one percentage point increase in the ICT share of total industry expenditure. The same trend is apparent over the 1996-2001 period though with somewhat reduced coefficients. In contrast, there was very little effect of computer spending on rates of employment change for university graduates.

When male and female workers are considered separately the same patterns are evident in the 1991-1996 period, suggesting that declining demand for less skilled workers was very general at that time. In the following five years the statistical significance drops markedly when workers are separated by gender.

The regressions were also estimated for the effects of hardware purchases and software and services purchases separated, each expressed as a proportion of industry total expenditure. In the case of software and services purchases both the coefficients and the levels of statistical significance are very similar to those for all computing purchases combined. However for hardware purchases there are no statistically significant findings at any educational level except for workers with postgraduate degrees, for whom the coefficients are substantial and positive. The stronger apparent effect for software and services may reflect the fact that expenditure on this input is nearly four times as great as expenditure on hardware, making it easier to observe statistically significant effects. The results with hardware purchases and software and services purchases separated are reported in table 4 .

A variety of additional control variables were added to the model to test whether these bivariate relationships between industry use of computers and changes in employment patterns are robust. These additional variables included: profitability (proxied by operating surplus), wages, and trade effects (exports and imports) each expressed as a proportion of total industry outlay. The results for this augmented model are reported in Table 5.

Table 3. Bivariate relationships between employment change by educational level and industry computer use

\begin{tabular}{|l|c|c|c|c|c|c|}
\hline \multirow{2}{*}{ All levels } & \multicolumn{2}{|c|}{ All workers } & \multicolumn{2}{c|}{ Male workers } & \multicolumn{2}{c|}{ Female workers } \\
\cline { 2 - 7 } & $\mathbf{1 9 9 1 - 1 9 9 6}$ & $\mathbf{1 9 9 6 - 2 0 0 1}$ & $1991-1996$ & $\mathbf{1 9 9 6 - 2 0 0 1}$ & $\mathbf{1 9 9 1 - 1 9 9 6}$ & $1996-2001$ \\
\hline No & -2.31 & -2.01 & -2.70 & -0.06 & -2.82 & 5.12 \\
qualifications & $(1.23)$ & $(0.72)$ & $(1.12)$ & $(0.50)$ & $(1.21)$ & $(0.48)$ \\
\hline School & -4.18 & -3.44 & -5.34 & -0.11 & -2.98 & 4.06 \\
Certificate & $*(2.03)$ & $(0.89)$ & $(1.67)$ & $(0.34)$ & $(1.49)$ & $(0.45)$ \\
\hline U.E./6th & -6.26 & -7.83 & -7.97 & -0.95 & -5.46 & 8.31 \\
Form & $* *(3.42)$ & $* *(3.07)$ & $* *(3.85)$ & $* *(4.43)$ & $*(2.26)$ & $(0.55)$ \\
\hline Bursary & -15.26 & -9.71 & -14.85 & -0.82 & -17.00 & 5.07 \\
& $* *(6.58)$ & $* *(3.72)$ & $* *(5.45)$ & $* *(6.05)$ & $* *(7.60)$ & $(0.32)$ \\
\hline Diploma & -18.05 & -4.66 & -18.30 & -0.52 & -18.23 & 9.04 \\
& $* *(5.93)$ & $(1.44)$ & $* *(6.47)$ & $* *(4.10)$ & $* *(3.80)$ & $(0.60)$ \\
\hline Bachelor's & -2.26 & 1.14 & -2.46 & 0.49 & -2.68 & 1.58 \\
degree & $(1.89)$ & $(0.41)$ & $(1.25)$ & $* *(2.94)$ & $(1.70)$ & $(0.22)$ \\
\hline Postgraduate & -0.71 & -6.66 & 0.18 & -0.11 & -0.06 & -4.86 \\
degree & $(0.17)$ & $(1.28)$ & $(0.04)$ & $(0.74)$ & $* *(5.00)$ & $(0.39)$ \\
\hline
\end{tabular}


Table 4: Bivariate relationships between employment change by educational level and industry computer use, with expenditure on hardware separated from software and services.

\begin{tabular}{|l|c|c|c|c|}
\hline \multirow{2}{*}{} & \multicolumn{2}{|c|}{ 1991-1996 } & \multicolumn{2}{c|}{ 1996-2001 } \\
\cline { 2 - 5 } & $\frac{\text { Hardware }}{\text { Total }}$ & $\frac{\text { Software/Serv's }}{\text { Total }}$ & $\frac{\text { Hardware }}{\text { Total }}$ & $\frac{\text { Software/Serv's }}{\text { Total }}$ \\
\hline \multirow{2}{*}{ All levels } & 2.40 & -2.94 & -3.32 & -1.81 \\
& $(0.22)$ & $(1.57)$ & $(0.34)$ & $(0.71)$ \\
\hline No & -4.33 & -4.16 & -10.73 & -2.02 \\
qualifications & $(0.49)$ & $(1.96)$ & $(1.06)$ & $(0.50)$ \\
School & -2.51 & -6.61 & -13.06 & -7.15 \\
\hline U.E./6th & $(0.26)$ & $* *(3.44)$ & $(1.48)$ & $* *(2.99)$ \\
Form & -0.38 & -16.06 & -8.51 & -9.84 \\
\hline Bursary & $(0.05)$ & $* *(8.50)$ & $(1.02)$ & $* *(4.36)$ \\
\hline Diploma & -11.64 & -18.53 & 4.19 & -5.73 \\
& $(0.95)$ & $* *(6.66)$ & $(0.41)$ & $*(2.09)$ \\
\hline Bachelor's & -4.32 & -1.91 & -3.65 & 2.05 \\
degree & $(0.44)$ & $(1.14)$ & $(0.40)$ & $(0.72)$ \\
\hline Postgraduate & -2.80 & -0.37 & -20.58 & -4.43 \\
degree & $(0.28)$ & $(0.08)$ & $(1.28)$ & $(1.16)$ \\
\hline & 37.97 & -4.25 & 21.30 & -4.80 \\
& $(1.78)$ & $(0.75)$ & $*(2.06)$ & $(1.18)$ \\
\hline
\end{tabular}

Table 5: Relationship between employment change by educational level and industry computer use. Comparison between bivariate results and those including controls for profitability, wages and trade.

\begin{tabular}{|l|c|c|c|c|}
\hline & \multicolumn{2}{|c|}{ Bivariate results } & \multicolumn{2}{c|}{ Results with controls } \\
\cline { 2 - 5 } & $1991-1996$ & $1996-2001$ & $1991-1996$ & $\mathbf{1 9 9 6 - 2 0 0 1}$ \\
\hline \multirow{2}{*}{ All levels } & -2.31 & -2.01 & -3.22 & -3.67 \\
& $(1.23)$ & $(0.72)$ & $(1.60)$ & $(1.21)$ \\
\hline No & -4.18 & -3.44 & -5.43 & -5.87 \\
qualifications & $*(2.03)$ & $(0.89)$ & $*(2.31)$ & $(1.40)$ \\
\hline School & -6.26 & -7.83 & -9.50 & -11.46 \\
Certificate & $* *(3.42)$ & $* *(3.07)$ & $* *(4.60)$ & $*(2.56)$ \\
\hline U.E./6th & -15.26 & -9.71 & -19.09 & -14.96 \\
Form & $* *(6.58)$ & $* *(3.72)$ & $* *(7.14)$ & $* *(2.78)$ \\
\hline Bursary & -18.05 & -4.66 & -21.81 & -10.40 \\
& $* *(5.93)$ & $(1.44)$ & $* *(5.19)$ & $(1.71)$ \\
\hline Diploma & -2.26 & 1.14 & -2.87 & 0.14 \\
& $(1.89)$ & $(0.41)$ & $(1.77)$ & $(0.05)$ \\
\hline Bachelor's & -0.71 & -6.66 & -0.96 & -8.40 \\
degree & $(0.17)$ & $(1.28)$ & $(0.41)$ & $(1.33)$ \\
\hline Postgraduate & 1.67 & -0.94 & 1.00 & -1.29 \\
degree & $(0.32)$ & $(0.26)$ & $(0.40)$ & $(0.32)$ \\
\hline
\end{tabular}

The relationship between industry spending on computing and the change in demand for workers of each skill level appears robust to the inclusion of the control variables. The estimates in the augmented model show small changes in the magnitude and no reduction in the statistical significance of the variable that proxies for industry use of computers, with the coefficients on the computing effect tending to be slightly higher than in the bivariate model.

\section{Summary and Implications}

In New Zealand the last 25 years have seen a marked decline in demand for less skilled workers, a pattern which is common to many of the developed countries and especially to the English speaking countries. This period has also been one of rapid technological change, notably with regard to the adoption of Information and Communication Technologies (ICTs) and the widespread 
workplace reorganization which new technologies have facilitated.

The results reported here suggest a strong correlation between changing patterns of labour demand and the ICT-intensiveness of industries. The demand for well qualified workers does not appear to be affected by ICT use, but the findings show a substantial and statistically significant decline in demand for workers with no qualifications beyond school level, and this decline is strongly correlated with the uptake of ICT. The trend was most marked between the Censuses of 1991 and 1996, and continued between 1996 and 2001 although at a reduced level. It would be interesting to see whether the change for the 1996-2001 period compared to 1991-1996 is still apparent when more recent data on computer purchases become available.

This pattern is consistent with the complementarity of computers for skilled workers and the substitutability of computers for unskilled workers. The international literature suggests that this complementarity is not so much a direct effect of computers as the indirect effect that automation facilitates workplace reorganization, which in turn leads to a changing pattern of labour demand. But whatever the exact path of the causality may be, these findings strongly support the hypothesis that the declining demand for less skilled workers is substantially affected by ICT uptake or the consequential changes which accompany it.

This finding has significant policy implications. The Government has stated its wish to encourage ICT upgrading as a growth promoting strategy ${ }^{1}$. However it seems likely that such a strategy would yield uneven benefits with less skilled workers ill placed to participate, and therefore tend to exacerbate the polarization of society into advantaged and disadvantaged groups. This suggests that an increased commitment to raising skill levels of the less qualified members of the workforce may be necessary if undesirable divisions in society are to be minimized.

\section{Notes}

${ }^{1}$ Growing an Innovative New Zealand. Available on the internet at http://www.beehive.govt.nz.

${ }^{2}$ Press Release by Hon. Steve Maharey and Hon Paul Swain, December 5, 2000 "Government releases 'digital divide' papers", available on the internet at http://www.executive.govt.nz/minister/maharey/divid e/pr.htm.

3 To reduce the computational burden associated with estimating models on such large samples, the dataset was organised into 20,000 cells defined by age, education, gender, income level and industry.

4 Regression estimates with alternative settings for missing values are available on request.

\section{References}

Acemoglu, Daron. (1998) Why do new technologies complement skills? Directed technical change and wage inequality. Quarterly Journal of Economics, 113: 1055-1089.

Acemoglu, Daron. (2001) Human Capital Policies and the Distribution of Income: A Framework for Analysis and Literature Review. Wellington : The Treasury.(Treasury working papers, 01/03) http://www.treasury.govt.nz/workingpapers/2001/ 01-3.asp

Acemoglu, Daron. (2002) Technical change, inequality and the labor market. Journal of Economic Literature, 40: 7-72.

Allen, Steven G. (1996) Technology and the wage structure (NBER Working Paper, 5534) Cambridge, MA : National Bureau of Economic Research.

Atkinson, A. B. (2001) A critique of the transatlantic consensus of rising income inequality. The World Economy, 24(4): 433-452.

Autor, David H, Katz, Lawrence F. and Krueger, Alan B. (1998) Computing inequality : Have computers changed the labor market? Quarterly Journal of Economics, 113(4): 1169-1213.

Bartel, A. and Lichtenberg, F. (1987) The comparative advantage of educated workers in implementing new technology. Review of Economics and Statistics, 69: 1-11.

Bartel, A and Sicherman, N. (1999) Technological change and wages: An interindustry analysis. Journal of Political Economy, 107: 285-325.

Berman, Eli., John Bound and Machin, Stephen. (1998) Implications of skill-biased technological change: international evidence. Quarterly Journal of Economics, 113: 1245-1279.

Borland, Jeff. (2000) Economic Explanations of Earnings Distribution Trends in the International Literature and Application to New Zealand. (Treasury working paper 00/16) Wellington. http://www.treasury.govt.nz/workingpapers/2000/ $\underline{00-16 . a s p}$

Bound, John and Johnson, George. (1995) What are the causes of rising wage inequality in the United States? Economic Policy Review, 1(1): 9-17.

Bresnahan, T. (1999) Computerisation and wage dispersion: An analytical reinterpretation. Economic Journal, 109(456): F390-F415

Bresnahan, Timothy F. Brynjolfsson, Erik and Hitt, Lorin M. (2002) Information technology, workplace organization, and the demand for 
skilled labor: Firm-level evidence. Quarterly Journal of Economics, 117(1): 339-376.

Bresnahan, Timothy F. and Trajtenberg, M. (1995) General purpose technologies: 'Engines of growth'? Journal of Econometrics, 65: 83-108.

Brynjolfsson, Erik and Hitt, Lorin M. (2000) Beyond computation: information technology, organizational transformation and business performance. Journal of Economic Perspectives, 14(4): 23-48.

David, Paul A (2000) Understanding digital technology's evolution and the path of measured productivity growth: present and future in the mirror of the past.

DiNardo, John E. and Pischke, Jorn-Steffen. (1997) The returns to computer use revisited: Have pencils changed the wage structure too? Quarterly Journal of Economics, 112(1): 291-303

Dixon, Sylvia. (1998) Growth in the dispersion of earnings, 1984-1997. Labour Market Bulletin, 1998(1\&2): 71-107

Engelbrecht, Hans-Jurgen. (2002) Gender and the information workforce: New Zealand evidence and issues. Prometheus, 19(2):1-20.

Freeman, Christopher, (1992) The Economics of Hope: Essays on Technical Change, Economic Growth and the Environment. Pinter, London.

Goldin, Claudia and Katz, Lawrence F. (1998) The origins of technology-skill complementarity. Quarterly Journal of Economics, 113: 693-732.

Helpman, Elhanan, ed. (1998) General Purpose Technologies and Economic Growth. Cambridge, MA : MIT Press.

Howell, David R. and Wolff, Edward N. (1992) Technical change and the demand for skills by US industries. Cambridge Journal of Economics: $127-$ 146.

Huffman, Wallace E. (1974) Decision making: the role of education. American Journal of Agricultural Economics, 56(1): 85-97.

Johnson, George E. (1997) Changes in earnings inequality: the role of demand shifts. Journal of Economic Perspectives, 11(2): 41-54

Juhn, Chinhui. (1999) Wage inequality and demand for skill: evidence from five decades. Industrial and Labor Relations Review, 52(3): 424-443.

Juhn, Chinhui, Murphy, Kevin M. and Pierce, Brooks (1993) Wage inequality and the rise in returns to skill. Journal of Political Economy, 101: 410-422.
Krueger, Alan. (1993) How computers have changed the wage structure: Evidence from microdata, 19841989. Quarterly Journal of Economics, 108: 33-60

Landau, Ralph, Taylor, Timothy and Wright, Gavin (eds), 1996: The Mosaic of Economic Growth. Stanford, CA: Stanford University Press.

Lawrence, Robert Z. (1995) U.S. wage trends in the 1980s: The role of international factors. Economic Policy Review, 1(1): 18-25.

Levy, Frank and Murnane, Richard J. (1992) U.S. earnings levels and recent inequality: a review of recent trends and proposed explanations. Journal of Economic Literature, 30(3): 1333-1381

Maani, Sholeh. (1999) Private and Public Returns to Investments in Secondary and Higher Education in New Zealand over Time: 1981-1996. Wellington : The Treasury. (Treasury working paper 99/2)

Martin, John. (1994) The extent of high unemployment in OECD countries. In: Federal Reserve Bank of Kansas City, 1994: Reducing Unemployment: A Symposium: 5-47.

Murphy, Kevin M. and Welch, Finis. (1993) Industrial change and the rising importance of skill. Chapter 3 in Danziger and Gottschalk, 1993: Uneven Tides: 101-132.

Nelson, Richard R and Phelps, Edmund S. (1966) Investment in humans, technological diffusion, and economic growth. American Economic Review, 56(2): 69-75.

Nickell, Stephen and Bell, Brian. (1995) The collapse in demand for the unskilled and unemployment across the OECD. Oxford Review of Economic Policy, 11(1): 40-62

Podder, Nripesh and Chatterjee, Srikanta (1998) Sharing the national cake in post reform New Zealand: income inequality trends in terms of income sources. Unpublished paper presented at the Annual Conference of the New Zealand Association of Economists, Wellington, September 1998. http://econ.massey.ac.nz/inequality.pdf

Pryor, Frederic L and Schaffer, David L. (1999) Who's not working and why: employment, cognitive skills, wages and the changing US labor market. Cambridge : Cambridge University Press.

Schultz, Theodore W. (1975) The value of the ability to deal with diequilibria. Journal of Economic Literature, 13(3) : 827-846.

Schultz, Theodore W. (1993) The economic importance of human capital in moderniation. Education Economics, 1(1): 13-19. 
StataCorp. (1997) Stata Statistical Software: Release 5.0. College Station: Stata Corporation. Statistics New Zealand, 2002: Inter-Industry Study 1996 126 Industries - Interim Release (Year ended March 1996). http://www.stats.govt.nz

Winkelmann, R. (1998) The economic benefits of schooling in New Zealand: comment and update. New Zealand Economic Papers 32(2): 187-195)
Wolff, Edward N. (2002) Computerization and structural change. Review of Income and Wealth, 48(1); 5975 .

Wood, Adrian. (1995) North-South Trade, Employment and Inequality: Changing Fortunes in a Skill Driven World. Oxford : Clarendon Press. 